\title{
Green tea extract induces genes related to browning of white adipose tissue and limits weight-gain in high energy diet-fed rat
}

\author{
Li-Han Chen ${ }^{a}$, Yi-Wen Chien ${ }^{b}$, Chung-Tiang Liang ${ }^{c}$, Ching-Hung Chan ${ }^{d}$, Meng-Han Fan ${ }^{d}$ and Hui-Yu Huang ${ }^{d}$

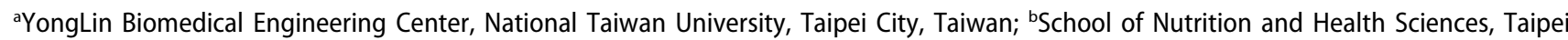 \\ Medical University, Taipei City, Taiwan; 'National Laboratory Animal Center, Taipei City, Taiwan; ${ }^{d}$ Department of Food Science, Nutrition, \\ and Nutraceutical Biotechnology, Shih Chien University, Taipei City, Taiwan
}

\section{ABSTRACT}

Background: A wealth of research has reported on the anti-obesity effects of green tea extract (GTE). Although browning of white adipose tissue (WAT) has been reported to attenuate obesity, no study has disclosed the effects of GTE on browning in Sprague Dawley rats.

Objectives: The aims of the study were to investigate the effects of GTE on anti-obesity and browning, and their underlying mechanisms.

Methods: Four groups of rats ( $n=10 /$ group) were used including a normal diet with vehicle treatment, and a high-energy diet (HED) with vehicle or GTE by oral gavage at 77.5 or $155 \mathrm{mg} / \mathrm{kg} /$ day for 8 weeks. Body weight, fat accumulation, and serum biochemical parameters were used to evaluate obesity. The gene expressions were analyzed using RT-qPCR and western blotting.

Results: GTE modulated HED-induced body weight, fat accumulation, and serum levels of triacylglycerol, total cholesterol, low-density lipoprotein, free fatty acids, aspartate aminotransferase, and alanine aminotransferase. Moreover, GTE enhanced the serum high-density lipoprotein. Most importantly, the biomarkers of beige adipose tissue were up-regulated in WAT in GTE-given groups. GTE induced genes involved in different pathways of browning, and reduced transducinlike enhancer protein-3 in WAT.

Conclusion: Our results suggest that GTE may improve obesity through inducing browning in HED-fed rats.

Abbreviations: ALT: Alanine transaminase; AST: Aspartate transaminase; BAT: Brown adipose tissue; BMP-7: Bone morphogenetic protein-7; BW: Body weight; CIDEA: Cell death activator; CPT-1: Carnitine palmitoyltransferase-1; EFP: Epididymal fat pad; FFA: Free fatty acid; FGF-21: Fibroblast growth factor21; GTE: Green tea extract; HDL: High-density lipoprotein; HED: high-energy diet; LDL: Low-density lipoprotein; MFP: Mesenteric fat pad; PGC-1a: Activates PPAR- $\gamma$ coactivator-1; PPAR- $\gamma$ : Peroxisome proliferator-activated receptor- $\gamma$; PRDM-16: PR domain containing 16; RFP: Renal fat pad; SD: Sprague Dawley; TC: Total cholesterol; TG: Triacylglycerol; TLE-3: Transducin-like enhancer protein-3: UCP-1: Uncoupling protein-1; WAT: White adipose tissue.

\section{ARTICLE HISTORY}

Received 26 April 2017

Accepted 20 June 2017

\section{KEYWORDS}

Anti-obesity; beige adipose tissue; browning of white adipose tissue; green tea extract; pathways of browning

\section{Introduction}

Obesity is one of the major risk factors for pathological disorders, including diabetes, hypertension, atherosclerosis, and cancer $[1,2]$. The prevalence of obesity is estimated to increase by $7 \%$ and $10 \%$ among men and women, respectively, by 2020 [3]. Therefore, to resolve the issue of obesity is an important requirement for human health. Several studies reported that food and food ingredients are good targets for improving obesity disorders, leading to the investigation of their anti-obesity mechanisms [4-6]. For example, green tea and its extracts were suggested to reduce body weight (BW) through inducing apoptosis, inhibiting adipogenesis, preventing energy uptake, enhancing lipolysis, elevating fatty acid oxidation-related genes, and increasing energy expenditure $[7,8]$. However, the effect of green tea on the browning of white adipose tissues (WAT) of Sprague Dawley (SD) rats is still unreported.

Nowadays, three types of adipose tissue are known, including WAT, brown adipose tissue (BAT), and beige adipose tissue. WAT is optimized to store energy in large lipid droplets for later use [9], and the accumulation of body fat in WAT leads to both hypertrophy and hyperplasia of white adipocytes [10]. These changes are associated with obesity-

CONTACT Hui-Yu Huang maggieh323@hotmail.com E Department of Food Science, Nutrition, and Nutraceutical Biotechnology, Shih Chien University, Taipei City, Taiwan

(c) 2017 The Author(s). Published by Informa UK Limited, trading as Taylor \& Francis Group.

This is an Open Access article distributed under the terms of the Creative Commons Attribution License (http://creativecommons.org/licenses/by/4.0/), which permits unrestricted use, distribution, and reproduction in any medium, provided the original work is properly cited. 
related diseases such as type-2 diabetes and an inflammatory response $[1,11]$. In contrast, BAT generates energy mostly in the form of heat [12], and promoting BAT activities was reported to prevent obesity [13]. Therefore, BAT was suggested as a potential target of anti-obesity therapy [14]. Recently, increasing research has focused on the other type of adipose tissue, beige adipose tissue, because beige adipose tissue was also identified as another potential candidate for obesity treatment due to its capacity to burn glucose and fat to produce heat [15]. Beige adipose tissue, traditionally seen as WAT, is a new form of adipose tissue and can be transformed from WAT [16]. Although beige adipose tissue and WAT are derived from Pax7- and Myf5precursor cells and express different gene signatures from BAT [17-19], beige adipose tissue is similar to BAT in that it has more mitochondria and higher expressions of thermogenesis and lipolysis genes [20].

Several genes of different pathways were suggested to regulate the browning of WAT. Peroxisome proliferator-activated receptor- $\gamma$ (PPAR- $\gamma$ ) is the master transcriptional regulator of fat differentiation, and in concert with the PR domain containing-16 (PRDM-16) activates PPAR- $\gamma$ coactivator- $1 \alpha$ (PGC- $1 \alpha$ ) to induce brown-selective genes [21-23]. Browning is also driven by the pathways involving either fibroblast growth factor-21 (FGF-21) or bone morphogenetic protein-7 (BMP-7) $[24,25]$. An increase of FGF-21 in WAT stabilizes PGC-1 $\alpha$ to enhance browning [24]. Moreover, EWS/YBX-1/BMP-7 pathway was suggested to mediate browning [25]. Conversely, transducin-like enhancer protein-3 (TLE-3), which suppresses brown-selective genes and induces white-selective genes, is involved in a negative regulation pathway of the browning process [26]. Differences between beige adipose tissue and WAT are observed in genes regulating them and also in mitochondrial and fatty acid oxidation-related genes. Compared to WAT, beige adipose tissue presents higher levels of uncoupling protein-1 (UCP-1), cell death activator (CIDEA), and carnitine palmitoyltransferase-1 (CPT-1) [18,27,28]. Enhancement of these genes transforms WAT into fat-oxidizing and energy-expending machines [29]. The aim of this study was to investigate the effects of green tea extract (GTE) on anti-obesity and browning of WAT in SD rats fed a high-energy diet (HED). Additionally, we analyzed the gene expressions following GTE treatment to evaluate GTE-induced pathways of browning of WAT. Therefore, the present study could demonstrate new insights into the anti-obesity mechanism induced by GTE.

\section{Materials and methods}

\section{Animals and diets}

Male SD rats (6 weeks old, $215 \mathrm{~g}$ ) were purchased from a local supplier (LASCO, Taipei, Taiwan) and singly housed during the study. Rats were given seven days to acclimate to their new environment under standard laboratory conditions (a 12/12-h light/dark cycle, $22 \sim 24^{\circ} \mathrm{C}, 40 \% \sim 60 \%$ humidity). All rats were fed ad libitum with the diets purchased from a local supplier. Ten rats given a normal diet (see Table 1 for ingredient composition) comprised the control group (C). The other 30 rats were fed an HED (see Table 1 for ingredient composition) and randomly and equally divided into three groups, including an HE group (given the HED), a 1X group (given the HED and $77.5 \mathrm{mg} / \mathrm{kg} /$ day of GTE), and a 2X group (given the HED and $155 \mathrm{mg} / \mathrm{kg} /$ day of GTE). For humans, giving $750 \mathrm{mg} /$ day of GTE was reported to protect against obesity [30]. The rat dose was converted from a human equivalent dose based on the body surface area by the following formula from the US Food and Drug Administration: assuming a human weight of $60 \mathrm{~kg}$, the dose for rat is $750 \mathrm{mg} /$ day $\div 60 \mathrm{~kg} \times 6.2=77.5 \mathrm{mg} / \mathrm{kg} /$ day; the conversion coefficient of 6.2 was used to account for differences between rats and humans. The GTE powder (Hong-Zhong Biotechnology, Tainan, Taiwan) was produced from green tea by standard procedures with a certificate of the analytical methods, and contained $83.5 \%$ total catechins, $38.5 \%$ epigallocatechin gallate (EGCG), $96.6 \%$ total polyphenols, and $1.8 \%$ caffeine (analyzed by HPLC). GTE was dissolved in $1 \mathrm{ml}$ of distilled water and orally administrated to the $1 \mathrm{X}$ and $2 \mathrm{X}$ groups by gavage at 09:00 every day for eight weeks, while $1 \mathrm{ml}$ of distilled water was given to the $\mathrm{C}$ and HE groups instead. Food and water intake levels were recorded every day, and BWs were measured weekly. Animals were sacrificed by $\mathrm{CO}_{2}$ at the end of the eighth week. All animal experiments were

Table 1. Ingredient composition of the diets fed to rats.

\begin{tabular}{lcc}
\hline Ingredient composition & Normal diet & High-energy diet \\
\hline Corn starch & $46.23 \%$ & $4.50 \%$ \\
Dextrin & $15.38 \%$ & $1.49 \%$ \\
Casein-vitamin free & $13.89 \%$ & $13.96 \%$ \\
Sucrose & $9.92 \%$ & $27.89 \%$ \\
Fructose & $0.00 \%$ & $19.91 \%$ \\
Powdered cellulose & $4.96 \%$ & $4.70 \%$ \\
Soybean Oil & $3.97 \%$ & $21.90 \%$ \\
AlN 93M Mineral Mix & $3.47 \%$ & $3.47 \%$ \\
AlN 93 Vitamin Mix & $0.99 \%$ & $0.99 \%$ \\
Choline bitartrate & $0.23 \%$ & $0.23 \%$ \\
L-Cystine & $0.17 \%$ & $0.17 \%$ \\
t-Butylhydroquinone & $0.79 \%$ & $0.79 \%$ \\
kcal/g & 3.8 & 4.50 \\
\hline
\end{tabular}


performed in accordance with the protocol (IACUC10,303) approved by the Institutional Animal Care and Use Committee (IACUC) of Shih Chien University.

\section{Adipose tissues sampling}

WATs from mesenteric, epididymal, and perirenal sites were collected, rinsed with PBS, and then weighed immediately. All samples were stored at $-80^{\circ} \mathrm{C}$ until the beginning of analysis.

\section{Serum biochemical parameters}

After eight hours of starving, rat blood was collected and serum was obtained by centrifugation at $3500 \mathrm{~g}$ for 10 minutes at $4^{\circ} \mathrm{C}$. Plasma triacylglycerol (TG), total cholesterol (TC), low-density lipoprotein (LDL), highdensity lipoprotein (HDL), alanine transaminase (ALT), and aspartate transaminase (AST) were measured using a Hitachi 7080 analyzer (Hitachi, Japan). The free fatty acid (FFA) concentration was determined by an enzymatic colorimetric assay according to the manual of a commercial kit (Boehringer Mannheim, Germany).

\section{Determination of the adipocyte size of WAT}

Epididymal fat pads (EFPs) were fixed in 4\% paraformaldehyde ( $\mathrm{pH} \mathrm{7.2)}$ at $4^{\circ} \mathrm{C}$ for 16 hours. EFP samples were dehydrated in absolute ethanol, cleared in xylene, and then embedded in paraffin. After cutting the paraffin into $4-\mu \mathrm{m}$ sections, sections were stained with Harris hematoxylin and counterstained with eosin, and digital images were taken under light microscopy (Nikon, Japan). To analyze the digital images, the area, approximate diameter, perimeter, and shape factor were measured in 10 adipocytes (five slides for each rat, 10 rats per group). The analysis of these results was performed using the Sigma ScanPro4 program (Sigma, USA).

\section{RNA extraction and quantitative RT-PCR (RT-qPCR)}

RNA was extracted using an RNeasy Mini kit (Qiagen, Germany), and $500 \mathrm{ng}$ of total RNA of each sample was reverse-transcribed with an iScript cDNA Synthesis Kit (Bio-Rad, USA) according to instructions of the manufacturer. A qPCR was performed in a MyiQ SingleColor Real-Time PCR Detection System (Bio-Rad), and sequences of gene-specific primers (Purigo, Taiwan) are shown in Table 2 . $\beta$-actin was used as an internal control for normalizing messenger (m)RNA levels of the tested genes.

\section{Western blot determination of UCP-1 and $\beta$-actin}

EFPs were homogenized in RIPA lysis buffer containing protease inhibitors (Sigma) for $30 \mathrm{~min}$ and then sonicated at $4^{\circ} \mathrm{C}$. After centrifuged $\left(16000 \times \mathrm{g}\right.$ for 10 minutes at $\left.4^{\circ} \mathrm{C}\right)$, the supernatant was collected. The concentration of protein was measured by the Bradford method with a protein assay kit (Bio-Rad). The protein from the lysate was loaded at $40 \mu \mathrm{g}$, separated by $10 \%$ sodium dodecyl sulfate polyacrylamide gel electrophoresis, and then transferred onto nitrocellulose membranes (Millipore, USA). The blots were hybridized with primary antibodies against UCP-1 (Proteintech Group, USA) and $\beta$-actin (Cell Signalling Technology, USA). The horseradish peroxidase activity was detected by an enhanced chemiluminescence system (UVP BioSpectrum Imaging System, Upland, USA) following incubation with the horseradish peroxidase-conjugated secondary antibodies (Cell Signalling Technology). The values were obtained by dividing the density of the band of UCP- 1 by that of $\beta$-actin from the same sample.

\section{Statistical analyses}

Data were analyzed by a one-way analysis of variance (ANOVA) with Tukey's post-hoc test. All results are presented as the mean \pm standard error of the mean. $\mathrm{p}$ values $<0.05$ were considered significant.

Table 2. Primer sequences used in the RT-qPCR.

\begin{tabular}{|c|c|c|c|}
\hline Gene & Gene accession numbers & Forward primers & Reverse primers \\
\hline PPAR- $\gamma$ & NM_013124.3 & GACCTCTCTGTGATGGATGAC & TCGCACTTTGGTATTCTTGGA \\
\hline PRDM-16 & NM_001291029.1 & GCAGACCCTGTGGGAGTCCTGAAA & GCTCCCCTGTGTGTGTCCTCAGAT \\
\hline BMP-7 & NM_001191856.2 & CGCTCCAAGACTCCAAAGAA & GGTCTCGGAAGCTAACATACAG \\
\hline FGF-21 & NM_130752.1 & CAACAACCAGATGGAACTCTCTA & GGTACACATTGTATCCGTCCTT \\
\hline PGC-1a & AY 237127.1 & GCCGGAGCAATCTGAGTTAT & GATCACCAAACAGCCGTAGA \\
\hline TLE-3 & NM_053400.1 & GATAGGCAGATGGACAGACAAG & GAGAAGATGGAGCAGAGAAACC \\
\hline UCP-1 & NM_012682.2 & AGGGTTTGCGCCTTCTTT & GGGACTTCATCAGCTCTTTCTT \\
\hline CPT-1 & NM_031559.2 & CGGAGCCAGGAGATATAGATAGA & GAATCTGACTGGGTGGGATTAG \\
\hline CIDEA & NM_001170467.1 & GGACACAGAGGAGTTCTTTCAG & CGAAGGTGACTCTGGCTATTC \\
\hline Leptin & NM_013076.3 & GGTTTCGTGGTGCTGACTAA & САCATCCTGTTCCGACTCTTAC \\
\hline Adiponectin & BC092565.1 & AAGTCTGGCTCCAAGTGTATG & GGTAGAGAAGGAAGCCTGTAAAT \\
\hline$\beta$-actin & NM_031144.3 & ACAGGATGCAGAAGGAGATTAC & ACAGTGAGGCCAGGATAGA \\
\hline
\end{tabular}




\section{Results}

\section{Food intake, BW, and the feed conversion efficiency}

The effect of GTE on obesity was investigated using male SD rats with HED-induced obesity. Weekly food intake of each rat was approximately $140 \sim 173 \mathrm{~g}$, and no difference was seen among all groups (Table 3 ). The average BW did not significantly differ between groups at week 0 . From the 2 nd week to the end of the trial, the HE group had significantly higher BW than the other groups. During the period of the study, average BW gains were $221.2 \pm 17.7,306.3 \pm 19.6,246.5 \pm 26.4$, and $241.0 \pm 20.9$ in the $\mathrm{C}, \mathrm{HE}, 1 \mathrm{X}$, and $2 \mathrm{X}$ groups, respectively (Figure 1). Although the weight of total food intake per rat was not different between the groups, the food conversion efficiency (Increase of BW / Total calories intake) was higher in the HE group than the $\mathrm{C}, 1 \mathrm{X}$, and $2 \mathrm{X}$ groups (Table 3 ). The $1 \mathrm{X}$ group showed slightly higher BW and food conversion efficiency than the $2 \mathrm{X}$ group, but the difference was not statistically significant. Group $\mathrm{C}$ with the lowest average BW gain indicated that obesity successfully occurred in HED-fed rats.

\section{Plasma biochemical parameters}

Plasma biochemistry was evaluated to assess the antiobesity effects of GTE in HED-fed SD rats. Group C had lower TG, TC, LDL, FFA, AST, and ALT than the HE group, and lower TG, TC, and ALT than the $1 \mathrm{X}$ and $2 \mathrm{X}$ groups. The HDL level was highest in the $\mathrm{C}$ group (Table 3). GTE treatment resulted in significant decreases in TG, TC, LDL, FFA, AST, ALT, and FFA, and an increase of HDL in both the $1 \mathrm{X}$ and $2 \mathrm{X}$ groups compared to the HE group. Moreover, a lower concentration of TC was found in the $2 \mathrm{X}$ group than in the $1 \mathrm{X}$ group (Table 3).

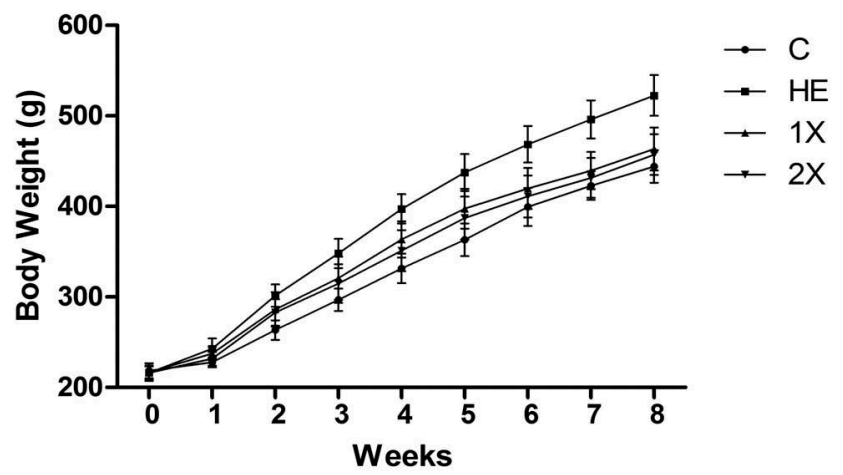

Figure 1. Body weights in eight weeks. C; vehicle control, $\mathrm{HE}$; HED vehicle control, 1X; HED with $77.5 \mathrm{mg} / \mathrm{kg} /$ day of GTE, 2X; HED with $155 \mathrm{mg} / \mathrm{kg} /$ day of GTE. Data are the mean \pm SEM ( $\mathrm{n}=10 \mathrm{rats} /$ group).

\section{Fat accumulation and compositions of WAT}

Effects of GTE on fat accumulation were studied by analyzing the weight of WAT and the size of adipocytes. Weights of epididymal, perirenal, and mesenteric WATs were lower in the $\mathrm{C}, 1 \mathrm{X}$, and $2 \mathrm{X}$ groups than in the HE group. Compared to the $\mathrm{C}$ group, the $1 \mathrm{X}$ group had higher weights of EFPs and renal fat pads (RFPs), and only RFPs were heavier in the $2 \mathrm{X}$ group. The body fat percentage of control rats was lower than those of HE and $1 \mathrm{X}$ rats, and both $1 \mathrm{X}$ and $2 \mathrm{X}$ rats had a lower body fat percentage than $\mathrm{HE}$ rats (Table 4). In addition, adipocytes of the EFPs were much smaller in rats of the $1 \mathrm{X}$ and $2 \mathrm{X}$ groups than in rats of the $\mathrm{HE}$ group (Figure 2).

\section{Leptin and adiponectin mRNA expressions}

Since our purpose was to understand the anti-obesity mechanism of GTE in rats fed with a HED, the expressions of mRNA were compared in three HED fed groups. mRNA expressions of leptin and adiponectin were

Table 3. Effects of GTE on the body weight, diet intake, food efficiency, and serum biochemical parameters in HED-fed rats.

\begin{tabular}{|c|c|c|c|c|}
\hline & C & HE & $1 X$ & $2 X$ \\
\hline Total food intake $(\mathrm{g}) / \mathrm{rat}$ & $1386.7 \pm 13.4^{\mathrm{a}}$ & $1382.0 \pm 18.9^{\mathrm{a}}$ & $1377.9 \pm 18.0^{\mathrm{a}}$ & $1376.2 \pm 19.1^{\mathrm{a}}$ \\
\hline Increase of BW/rat & $221.2 \pm 17.7^{\mathrm{a}}$ & $306.3 \pm 19.6^{c}$ & $252.5 \pm 24.7^{b}$ & $247.2 \pm 16.6^{\mathrm{b}}$ \\
\hline FCE (\%) & $15.9 \pm 1.3^{\mathrm{a}}$ & $22.2 \pm 1.4^{c}$ & $18.4 \pm 1.8^{\mathrm{b}}$ & $17.9 \pm 1.3^{\mathrm{b}}$ \\
\hline $\mathrm{TG}(\mathrm{mg} / \mathrm{dl})$ & $44.3 \pm 3.0^{\mathrm{a}}$ & $79.0 \pm 10.3^{c}$ & $55.1 \pm 7.5^{b}$ & $52.1 \pm 3.9^{b}$ \\
\hline $\mathrm{TC}(\mathrm{mg} / \mathrm{dl})$ & $42.0 \pm 6.4^{\mathrm{a}}$ & $69.5 \pm 7.8^{\mathrm{d}}$ & $61.2 \pm 6.6^{c}$ & $53.3 \pm 7.5^{b}$ \\
\hline $\operatorname{LDL}(\mathrm{mg} / \mathrm{dl})$ & $5.5 \pm 0.7^{\mathrm{a}}$ & $7.8 \pm 1.2^{b}$ & $6.3 \pm 1.6^{\mathrm{a}}$ & $6.0 \pm 0.9^{\mathrm{a}}$ \\
\hline $\mathrm{HDL}(\mathrm{mg} / \mathrm{dl})$ & $20.1 \pm 4.0^{c}$ & $13.4 \pm 1.4^{\mathrm{a}}$ & $16.0 \pm 1.3^{\mathrm{b}}$ & $16.1 \pm 1.5^{b}$ \\
\hline FFA $(\mu M)$ & $3.2 \pm 1.1^{\mathrm{a}}$ & $4.9 \pm 0.9^{b}$ & $3.9 \pm 0.5^{\mathrm{a}}$ & $3.5 \pm 0.4^{\mathrm{a}}$ \\
\hline AST (U/L) & $126.9 \pm 39.4^{\mathrm{a}}$ & $224.1 \pm 79.3^{b}$ & $171.9 \pm 13.7^{\mathrm{a}}$ & $163.1 \pm 15.2^{\mathrm{a}}$ \\
\hline ALT $(U / L)$ & $33.1 \pm 4.6^{\mathrm{a}}$ & $58.6 \pm 9.7^{c}$ & $47.9 \pm 6.7^{b}$ & $43.1 \pm 11.6^{b}$ \\
\hline
\end{tabular}

Control, vehicle control; HE, HED vehicle control; $1 X$, HED with $77.5 \mathrm{mg} / \mathrm{kg} /$ day of GTE; $2 X$, HED with $155 \mathrm{mg} / \mathrm{kg} /$ day of GTE. All values are the mean \pm SEM $(n=10 \mathrm{rats} / \mathrm{group})$. Different superscript letters $(\mathrm{a}, \mathrm{b}, \mathrm{c})$ indicate a significant difference at $p<0.05$ by a one-way ANOVA with Tukey's post-hoc test. BW, body weight; FCE, food conversion efficiency (Increase of BW/Total calories intake); TG, triacylglycerol; TC total cholesterol; FFA, free fatty acids; AST, aspartate transaminase; ALT, alanine transaminase. 
Table 4. Effects of GTE on the mass of the EFP, RFP, MFP, and total body fat in HED-fed rats.

\begin{tabular}{|c|c|c|c|c|}
\hline & C & $\mathrm{HE}$ & $1 \mathrm{X}$ & $2 X$ \\
\hline $\operatorname{EFP}(\mathrm{q})$ & $6.6 \pm 0.9^{a}$ & $12.4 \pm 1.9^{c}$ & $8.9 \pm 1.5^{b}$ & $7.5 \pm 2.0^{\mathrm{ab}}$ \\
\hline $\operatorname{RFP}(\mathrm{g})$ & $10.9 \pm 1 .^{\mathrm{a}}$ & $20.0 \pm 1.7^{c}$ & $14.8 \pm 2.2^{\mathrm{b}}$ & $13.6 \pm 1.8^{\mathrm{b}}$ \\
\hline MFP $(g)$ & $5.6 \pm 1.2^{\mathrm{a}}$ & $9.7 \pm 1.6^{\mathrm{b}}$ & $6.9 \pm 1.3^{\mathrm{a}}$ & $6.3 \pm 1.5^{\mathrm{a}}$ \\
\hline $\begin{array}{l}\text { Body fat } \\
\text { percentage (\%) }\end{array}$ & $5.1 \pm 0.6^{a}$ & $8.0 \pm 0.9^{c}$ & $6.6 \pm 0.8^{b}$ & $6.0 \pm 0.8^{\mathrm{ab}}$ \\
\hline \multicolumn{5}{|c|}{$\begin{array}{l}\text { Control, vehicle control; HE, HED vehicle control; } 1 \mathrm{X} \text {, HED with } \\
77.5 \mathrm{mg} / \mathrm{kg} / \mathrm{day} \text { of GTE; } 2 \mathrm{X}, \mathrm{HED} \text { with } 155 \mathrm{mg} / \mathrm{kg} / \mathrm{day} \text { of GTE. All } \\
\text { values are the mean } \pm \mathrm{SEM}(n=10 \mathrm{rats} / \mathrm{group}) \text {. Different superscript } \\
\text { letters }(\mathrm{a}, \mathrm{b}, \mathrm{c}) \text { indicate a significant difference at } p<0.05 \text { by a one- } \\
\text { way ANOVA with Tukey's post-hoc test. }\end{array}$} \\
\hline
\end{tabular}
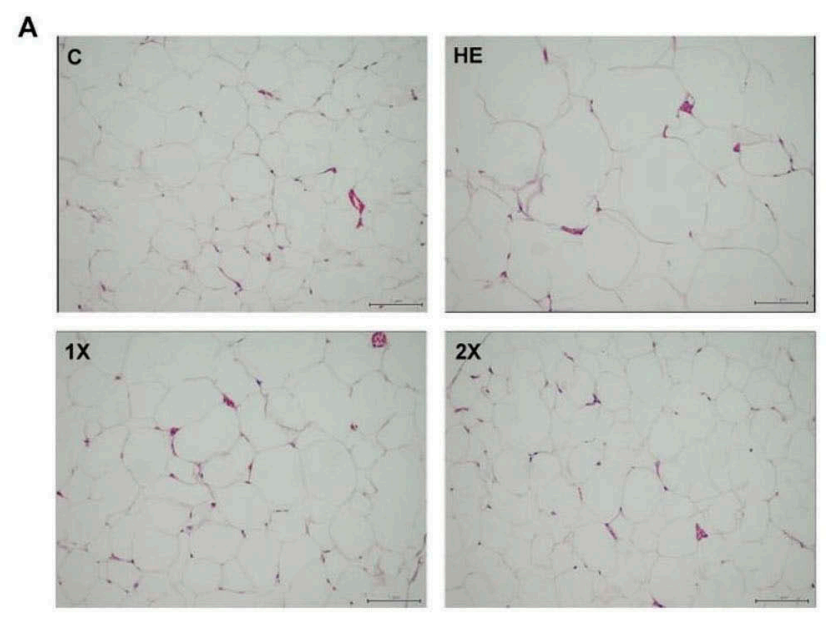

B

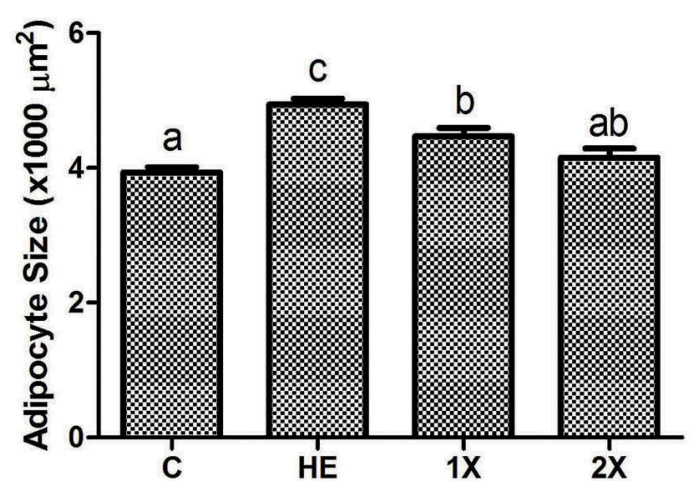

Figure 2. Histological analysis of epididymal fat pads stained with hematoxylin-eosin. C; vehicle control, HE; HED vehicle control, 1X; HED with $77.5 \mathrm{mg} / \mathrm{kg} /$ day of GTE, 2X; HED with $155 \mathrm{mg} / \mathrm{kg} /$ day of GTE. (a) Sections of epididymal fat pads fixed and stained with hematoxylin-eosin to visualize adipocytes (original magnification $\times 200$ ). (b) Adipocytes were analyzed with an image analysis system and quantified. All values are the mean \pm SEM ( $n=10$ rats/group). Different superscript letters $(a, b, c)$ indicate a significant difference at $p<0.05$ by a one-way ANOVA with Tukey's post-hoc test. Scale bar $=50 \mu \mathrm{M}$.

measured by an RT-qPCR. Leptin was higher in the HE group than in the $1 \mathrm{X}$ and $2 \mathrm{X}$ groups, and adiponectin was higher in the $1 \mathrm{X}$ and $2 \mathrm{X}$ groups than in the HE group. Although the $2 \mathrm{X}$ group showed higher expression of adiponectin than the $1 \mathrm{X}$ group, the difference was not significant (Figure 3).

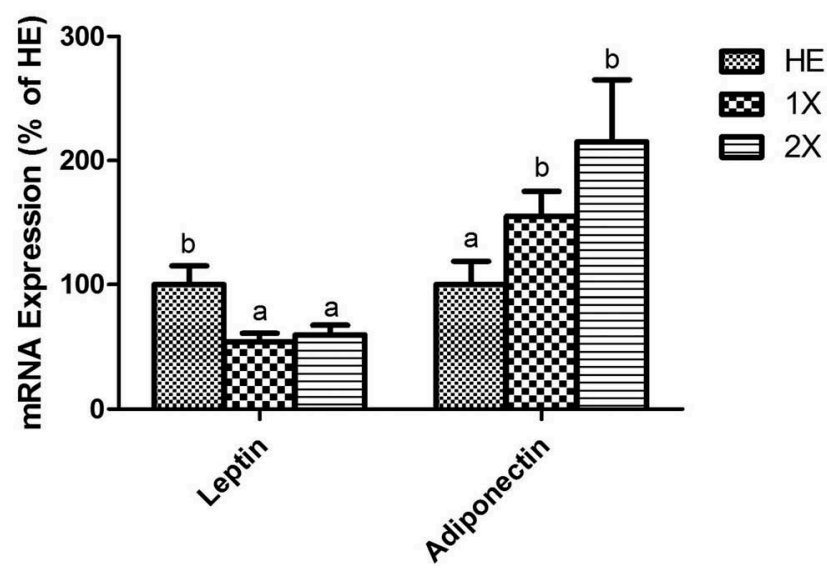

Figure 3. Expressions of leptin and adiponectin in the EFPs. HE; HED vehicle control, 1X; HED with $77.5 \mathrm{mg} / \mathrm{kg} /$ day of GTE, $2 X$; HED with $155 \mathrm{mg} / \mathrm{kg} /$ day of GTE. All values are the mean \pm SEM ( $n=10$ rats/group). Different superscript letters ( $a$ and $b$ ) indicate a significant difference at $p<0.05$ by a one-way ANOVA with Tukey's posthoc test.

\section{Expressions of beige-regulating and thermogenic genes in EFPs}

Several genes that regulate the transformation of white into beige adipose tissue and thermogenesis were measured by an RT-qPCR to evaluate the effect of GTE on the acquisition of BAT and beige adipose tissue characteristics by white adipocytes. PPAR- $\gamma$, PRDM-16, BMP-7, FGF-21, and PGC-1a, which drive development of beige adipose tissue, were significantly higher in the $1 \mathrm{X}$ and $2 \mathrm{X}$ groups than in the HE group. Moreover, TLE-3, which suppresses brown-selective genes and induces white-selective genes, was downregulated in the $1 \mathrm{X}$ and $2 \mathrm{X}$ groups (Figure 4(a)). Consistently, the biomarkers of browning, including UCP-1, CPT-1, and CIDEA, were upregulated in the $1 \mathrm{X}$ and $2 \mathrm{X}$ groups. Expressions of these genes did not differ between the $1 \mathrm{X}$ and $2 \mathrm{X}$ groups (Figure 4(b)). Similar to the result of mRNA expression, the protein levels of UCP-1 were significantly higher in the GTEtreated groups than the HE group and were not different between the $1 \mathrm{X}$ and $2 \mathrm{X}$ groups (Figure $4(\mathrm{c}, \mathrm{d})$ ).

\section{Discussion}

The anti-obesity mechanisms of GTE became an important topic in nutritional and food science research because beneficial effects of GTE against obesity were demonstrated in human and animal models $[7,8,31]$. In the present study, we provide evidence that GTE significantly improved obesity phenomena, such as BW, fat weight, the adipocyte size, and plasma chemical parameters in rats with HED-induced obesity. 
A

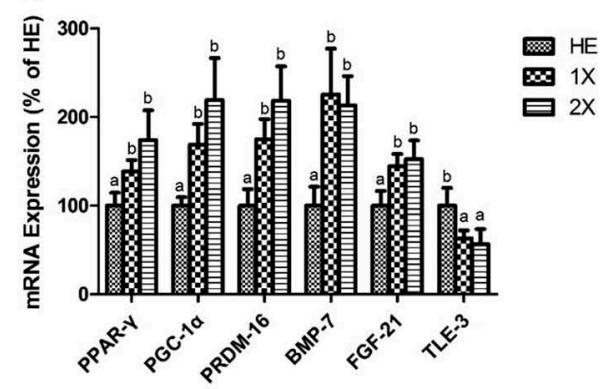

C
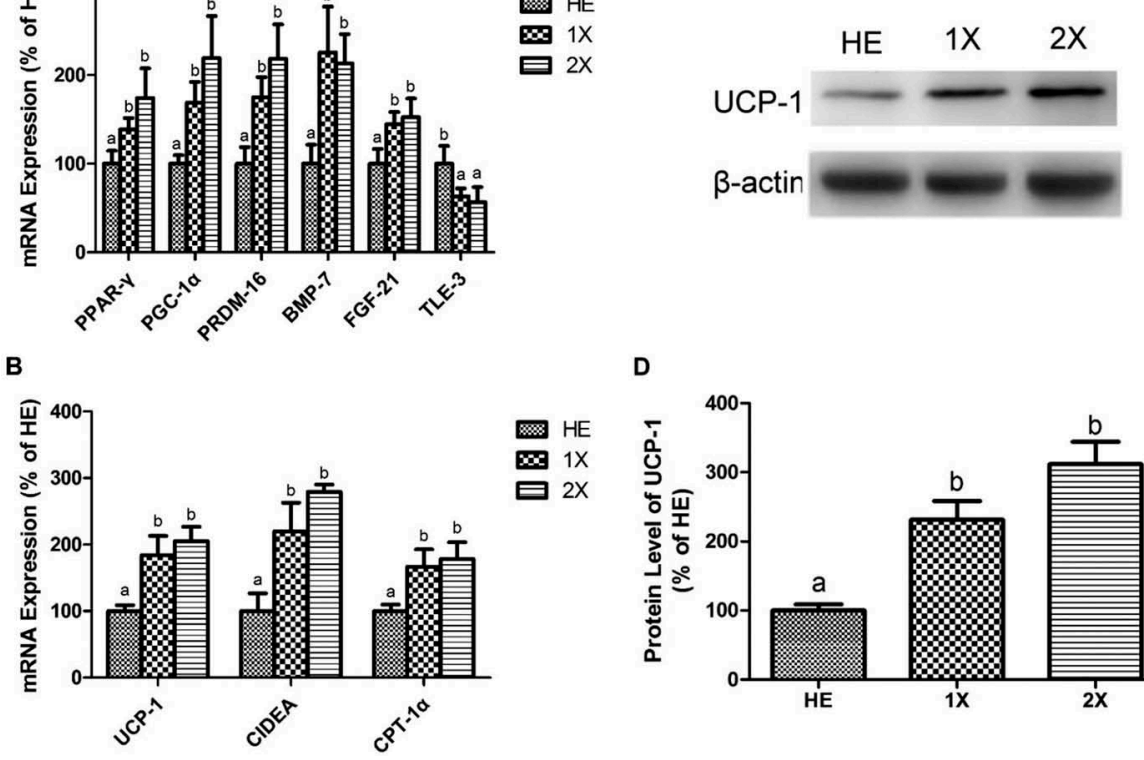

D

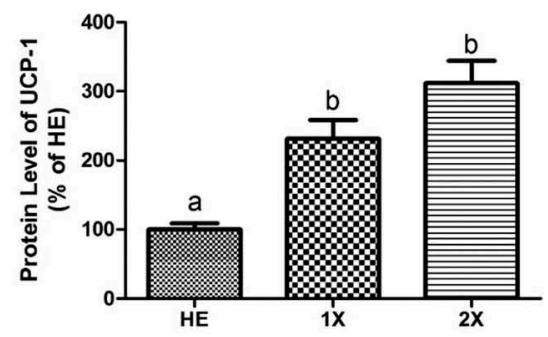

Figure 4. Expressions of genes related to beige transformation and thermogenesis in the EFPs. HE; HED vehicle control, $1 \mathrm{X}$; HED with $77.5 \mathrm{mg} / \mathrm{kg} /$ day of GTE, 2X; HED with $155 \mathrm{mg} / \mathrm{kg} /$ day of GTE. Genes related to (a) beige transformation and (b) thermogenesis were detected by an RT-qPCR. Representative blots (c) and protein levels (d) of UCP-1 were detected using western blotting. All values are the mean \pm SEM $(n=10$ rats/group). Different superscript letters $(a$ and $b)$ indicate a significant difference at $p<0.05$ by a one-way ANOVA with Tukey's post-hoc test.

The reduction of leptin and induction of adiponectin in the study also indicated that GTE modulated obesity in rats. Moreover, genes upregulated in beige adipose tissue were higher in the $1 \mathrm{X}$ and $2 \mathrm{X}$ groups compared to the HE group; and TLE-3, a beige adipose tissue transformation suppressor [26], was downregulated in the $1 \mathrm{X}$ and $2 \mathrm{X}$ groups. To our knowledge, this is the first paper revealing that GTE alone can induce the biomarkers of beige adipose tissue and the multiple pathways of browning that involve either PPAR- $\gamma$, PRDM-16, FGF-21, BMP-7, or TLE-2 associated with a prevention of HED-induced obesity in SD rats.

Beige adipose tissue is thought to be a potential target of anti-obesity therapy due to its capacity for oxidizing lipids and dissipating energy [20,32]. In addition, the browning of WAT was reported to be highly correlated with the anti-obesity effect without an increase in BAT function. For example, transgenic expression of PRDM-16 in WAT promoted the development of beige adipose tissue and resistance to obesity without enhancing the BAT mass [33]. Moreover, UCP-1 overexpression in adipose tissue suppressed obesity [13]. Since PRDM-16 and UCP1 are highly expressed in beige adipose tissue, an increase of beige adipose tissue should resist weight gain [23]. Therefore, determining the level of browning of WAT could help assess the anti-obesity effect of GTE. Browning is regulated by several pathways.
PPAR- $\gamma$, PRDM-16, and FGF-21, belonging to two different pathways, induced PGC-1 $\alpha$ to enhance expressions of genes involved in thermogenesis and fatty acid oxidation, such as UCP-1 [34], CIDEA $[35,36]$, and CPT-1 [37,38]. Moreover, BMP-7 was a member of EWS/YBX-1/BMP-7 pathway, which drives browning by upregulating UCP-1 and downregulating the WAT-specific marker, TCF21 [39]. In contrast, TLE-3, an inhibitor of PRDM-16, suppresses the browning of WAT [26]. In the present study, GTE significantly induced PPAR- $\gamma$, PRDM-16, PGC-1a, BMP-7, and FGF-21, and reduced TLE-3, which was associated with enhancement of the browning biomarkers, UCP-1, CIDEA, and CPT-1, in the $1 \mathrm{X}$ and $2 \mathrm{X}$ groups compared to the HE group. These results revealed that WAT seemed to transform to beige adipose tissue within eight weeks when SD rats were given GTE daily. Sae-tan et al. [40] reported that a combination of decaffeinated green tea and voluntary exercise induced genes related to browning in mice fed high fat diets, but the browning effect was not observed when the mice were given only green tea [40]. Since exercise had already been linked to browning [41], the role of green tea in regulation of browning was still a puzzle. Moreover, they did not provided any physiological or weight data following treatments. Herein, we provide the first evidence that GTE alone was sufficient to 
induce browning-related genes in WAT, which was accompanied by a significant anti-obesity effect in HED-fed rats.

Browning is defined as a process that the expression of UCP-1 increases in WAT [26]. Browning has been observed in EFP and used for investigating browning in many previous studies $[21,34,40,42-44]$. Therefore, the gene expressions of EFP are undoubtedly important to evaluate if GTE induces browning in this study. Our results indicate that GTE could be able to induce browning, because the GTE up-regulated the biomarkers of beige and the pathways of browning in EFP. Since EFP was suggested to be least able to induce coldderived browning [15] and to predominantly contain white adipocytes [41], browning may also occur in subcutaneous, renal, and mesenteric WATs post the treatment of GTE. However, more experiments are needed to understand the effect of GTE on browning in other WATs.

PPAR- $\gamma$ has tissue-specific effects [45]. In adipocytes, PPAR- $\gamma$ is known for its anti-obesity capability and insulin sensitization. PPAR- $\gamma$ enhances fatty acid uptake and adipogenesis in WAT to reverse insulin resistance [46], but upregulation of PPAR- $\gamma$ does not necessarily cause an increase in BW [47,48]. Moreover, Tian et al. [49] demonstrated that green tea polyphenols induced the extracellular signal-regulated kinase (ERK)1/2-PPAR- $\gamma$-adiponectin pathway followed by reduction of fat deposits [49]. Therefore, it is not surprising that a PPAR- $\gamma$ agonist was reported to have anti-diabetes and anti-obesity capabilities [50]. For the anti-obesity effect, PPAR- $\gamma$ can improve HED-induced obesity through browning of WAT and also upregulating adiponectin. Adiponectin is known to increase fatty acid oxidation and insulin sensitivity and prevent obesity and inflammation [51-53]. In the present study, we showed that both PPAR- $\gamma$ and adiponectin increased following GTE treatment of HED-fed rats. Although the concentration of circulating adiponectin was not determined, an increase of circulating adiponectin was probable following GTE treatment due to the higher mRNA levels of adiponectin in WAT of the GTE-treated groups than the HE group. Circulating adiponectin is mainly secreted by adipocyte, and positive correlation was shown between the mRNA level of adiponectin and the concentration of circulating adiponectin [49,54-57]. Moreover, the increase of PPAR- $\gamma$ mRNA in WAT was indicated to be associated with an increase of circulating adiponectin in the previous studies $[49,58]$. Thus, the results suggest that GTE might induce anti-obesity, antiinflammatory, and insulin sensitization effects of adiponectin via upregulation of PPAR- $\gamma$ in adipocytes. For detailing the systemic effect of GTE via adiponectin, a further study, such as to measure the concentration of circulating adiponectin, should be performed in the future.

In the present study, the $\mathrm{C}$ group was designed for evaluating if obesity was successfully induced by HED in the rats. Moreover, the results of the groups fed with a HED (HE, 1X, and 2X groups) were sufficient to support that GTE could induce browning-related genes and limit weight gain in HED-fed rats. Therefore, the gene expressions in WAT were not analyzed. Although gene expressions of the $\mathrm{C}$ group were not determined, GTE seemed to prevent the down-regulation of browning-related genes in HEDfed rats because lower mRNA expressions of browning-related genes in WAT were reported in the previous studies $[40,59,60]$. However, further study is necessary to investigate effects of GTE in the rats fed with different diets.

The anti-obesity effects of GTE are usually evaluated by physical differences in the bodies between rats given and those not given GTE. The GTE used in the current study significantly reduced increases in BW, WAT, and adipocyte size. The results indicated that obesity was modulated when HED-fed rats were given GTE. Furthermore, GTE-administered rats had lower levels of TG, TC, LDL, and FFA, and a higher level of HDL in serum. Increasing TG, TC, LDL, and FFA and decreasing HDL are frequently associated with cardiovascular disease, which is one of the obesity-related diseases. Since high serum FFA levels were observed in obese and diabetic patients [61] and promote hepatic steatosis, the GTE may prevent hepatic steatosis by reducing FFA levels. Preventing hepatic steatosis was also supported by our observation that GTE-administered rats showed lower serum ALT and AST levels which were correlated with hepatic steatosis and injury in obese mice [62]. Therefore, GTE could improve HED-induced obesity and might prevent its derivative diseases.

The effects of functional foods are influenced by the dose administered [63-69]. Overdosing results in toxicity $[63,64]$, and an inadequate dose leads to low efficiency [65-69]. A high dose of GTE (EGCG > $100 \mathrm{mg} / \mathrm{kg} /$ day) increases serum ALT and AST levels due to induction of liver toxicity [64]. Since lower levels of ALT and AST were shown in the $1 \mathrm{X}$ and 2X groups compared to the HE group, neither dose of GTE used in this study appeared to cause liver injury. To understand the dose effect, we treated HED-fed rats with two different doses of GTE. Previous studies reported that receiving GTE at $750 \mathrm{mg} /$ day significantly reduced the BW of human subjects $[30,70]$. 
According to a formula from the US Food and Drug Administration, $77.5 \mathrm{mg} / \mathrm{kg} /$ day of GTE for an SD rat is equivalent to $750 \mathrm{mg} /$ day for a $60-\mathrm{kg}$ human. Therefore, 77.5 and $155 \mathrm{mg} / \mathrm{kg} /$ day of GTE were used in the current study. Our results showed that when HED-fed rats were given $155 \mathrm{mg} / \mathrm{kg} /$ day of GTE (2X group), their $\mathrm{BW}$, fat weight, plasma chemical parameters, and adipocyte size were slightly better than those of rats given $77.5 \mathrm{mg} / \mathrm{kg} /$ day of GTE (1X group); however, no statistical difference in these obesity parameters was shown between the $1 \mathrm{X}$ and 2X groups. Similarly, expressions of beige-related genes also are higher in the $2 \mathrm{X}$ group but did not statistically differ between the $1 \mathrm{X}$ and $2 \mathrm{X}$ groups. Therefore, 77.5 and $155 \mathrm{mg} / \mathrm{kg} /$ day of GTE seemed to be efficient doses for an anti-obesity effect, but we cannot exclude that the anti-obesity effects may be enhanced by a higher dose of GTE.

In summary, our study presents that GTE alone is sufficient to promote the biomarkers of beige adipose tissue and multiple pathways of browning in WAT and to safely improve HED-induced obesity in SD rats.

\section{Author contributions}

Li-Han Chen conducted research and wrote the paper; Chung-Tiang Liang, Ching-Hung Chan, and Meng-Han Fan conducted research; Yi-Wen Chien wrote the paper. Hui-Yu Huang designed the research, supervised the project, and wrote the paper. All authors discussed the results and contributed to the manuscript.

\section{Disclosure statement}

No potential conflict of interest was reported by the authors.

\section{Funding}

Funds were raised by the authors.

\section{References}

[1] Kopelman PG. Obesity as a medical problem. Nature. 2000;404:635-643.

[2] Visscher TL, Seidell JC. The public health impact of obesity. Annu Rev Public Health. 2001;22:355-375.

[3] Bibbins-Domingo K, Chertow GM, Coxson PG, et al. Projected effect of dietary salt reductions on future cardiovascular disease. N Engl J Med. 2010;362:590-599.

[4] Choi KM, Lee YS, Shin DM, et al. Green tomato extract attenuates high-fat-diet-induced obesity through activation of the ampk pathway in c57bl/6 mice. J Nutr Biochem. 2013;24:335-342.
[5] Bhaswant M, Poudyal H, Mathai ML, et al. Green and black cardamom in a diet-induced rat model of metabolic syndrome. Nutrients. 2015;7:7691-7707.

[6] Okuda MH, Zemdegs JC, de Santana AA, et al. Green tea extract improves high fat diet-induced hypothalamic inflammation, without affecting the serotoninergic system. J Nutr Biochem. 2014;25:1084-1089.

[7] Huang J, Wang Y, Xie Z, et al. The anti-obesity effects of green tea in human intervention and basic molecular studies. Eur J Clin Nutr. 2014;68:1075-1087.

[8] Rains TM, Agarwal S, Maki KC. Antiobesity effects of green tea catechins: a mechanistic review. J Nutr Biochem. 2011;22:1-7.

[9] Scherer PE. Adipose tissue: from lipid storage compartment to endocrine organ. Diabetes. 2006;55:1537-1545.

[10] Shepherd PR, Gnudi L, Tozzo E, et al. Adipose cell hyperplasia and enhanced glucose disposal in transgenic mice overexpressing glut 4 selectively in adipose tissue. J Biol Chem. 1993;268:22243-22246.

[11] Haslam DW, James WP. Obesity. Lancet. 2005;366:1197-1209.

[12] Klaus S. Functional differentiation of white and brown adipocytes. Bioessays. 1997;19:215-223.

[13] Kopecky J, Clarke G, Enerback S, et al. Expression of the mitochondrial uncoupling protein gene from the ap2 gene promoter prevents genetic obesity. J Clin Invest. 1995;96:2914-2923.

[14] Cypess AM, Kahn CR. Brown fat as a therapy for obesity and diabetes. Curr Opin Endocrinol Diabetes Obes. 2010;17:143-149.

[15] Nedergaard J, Cannon B. The browning of white adipose tissue: some burning issues. Cell Metab. 2014;20:396-407.

[16] Vitali A, Murano I, Zingaretti MC, et al. The adipose organ of obesity-prone c57bl/6j mice is composed of mixed white and brown adipocytes. J Lipid Res. 2012;53:619-629.

[17] Wu J, Bostrom P, Sparks LM, et al. Beige adipocytes are a distinct type of thermogenic fat cell in mouse and human. Cell. 2012;150:366-376.

[18] Seale P, Bjork B, Yang W, et al. Prdm16 controls a brown fat/skeletal muscle switch. Nature. 2008;454:961-967.

[19] Sharp LZ, Shinoda K, Ohno H, et al. Human bat possesses molecular signatures that resemble beige/brite cells. PLoS One. 2012;7:e49452.

[20] Wu J, Cohen P, Spiegelman BM. Adaptive thermogenesis in adipocytes: is beige the new brown? Genes Dev. 2013;27:234-250.

[21] Petrovic N, Walden TB, Shabalina IG, et al. Chronic peroxisome proliferator-activated receptor gamma (ppargamma) activation of epididymally derived white adipocyte cultures reveals a population of thermogenically competent, ucp1-containing adipocytes molecularly distinct from classic brown adipocytes. J Biol Chem. 2010;285:7153-7164.

[22] Bostrom P, Wu J, Jedrychowski MP, et al. A pgc1-alphadependent myokine that drives brown-fat-like development of white fat and thermogenesis. Nature. 2012;481:463-468. 
[23] Harms M, Seale P. Brown and beige fat: development, function and therapeutic potential. Nat Med. 2013;19:1252-1263.

[24] Fisher FM, Kleiner S, Douris N, et al. Fgf21 regulates pgc-1alpha and browning of white adipose tissues in adaptive thermogenesis. Genes Dev. 2012;26:271-281.

[25] Seale P. Transcriptional regulatory circuits controlling brown fat development and activation. Diabetes. 2015;64:2369-2375.

[26] Villanueva CJ, Vergnes L, Wang J, et al. Adipose subtype-selective recruitment of tle 3 or prdm16 by ppar gamma specifies lipid storage versus thermogenic gene programs. Cell Metabo. 2013;17:423-435.

[27] Kajimura S, Seale P, Kubota K, et al. Initiation of myoblast to brown fat switch by a prdm16-c/ebp-beta transcriptional complex. Nature. 2009;460:1154-1158.

[28] Rosell M, Kaforou M, Frontini A, et al. Brown and white adipose tissues: intrinsic differences in gene expression and response to cold exposure in mice. Am J Physiol Endocrinol Metab. 2014;306:E945-E964.

[29] Orci L, Cook WS, Ravazzola M, et al. Rapid transformation of white adipocytes into fat-oxidizing machines. $\mathrm{P}$ Natl Acad Sci USA. 2004;101:2058-2063.

[30] Auvichayapat P, Prapochanung M, Tunkarnnerdthai O, et al. Effectiveness of green tea on weight reduction in obese thais: a randomized, controlled trial. Physiol Behav. 2008;93:486-491.

[31] Xu Y, Zhang M, Wu T, et al. The anti-obesity effect of green tea polysaccharides, polyphenols and caffeine in rats fed with a high-fat diet. Food Funct. 2015;6:297-304.

[32] Kajimura S, Spiegelman BM, Seale P. Brown and beige fat: physiological roles beyond heat generation. Cell Metabo. 2015;22:546-559.

[33] Seale P, Conroe HM, Estall J, et al. Prdm16 determines the thermogenic program of subcutaneous white adipose tissue in mice. J Clin Invest. 2011;121:96-105.

[34] Cao L, Choi EY, Liu XL, et al. White to brown fat phenotypic switch induced by genetic and environmental activation of a hypothalamic-adipocyte axis. Cell Metabo. 2011;14:324-338.

[35] Servera M, López N, Serra F, et al. Expression of "brown-in-white" adipocyte biomarkers shows gender differences and the influence of early dietary exposure. Genes Nutr. 2014;9:372.

[36] Kleiner S, Mepani RJ, Laznik D, et al. Development of insulin resistance in mice lacking pgc-1alpha in adipose tissues. Proc Natl Acad Sci USA. 2012;109:9635-9640.

[37] Wu J, Jun HJ, McDermott JR. Formation and activation of thermogenic fat. Trends Genet. 2015;31:232-238.

[38] Vega RB, Huss JM, Kelly DP. The coactivator pgc-1 cooperates with peroxisome proliferator-activated receptor alpha in transcriptional control of nuclear genes encoding mitochondrial fatty acid oxidation enzymes. Mol Cell Biol. 2000;20:1868-1876.

[39] Elsen M, Raschke S, Tennagels N, et al. Bmp4 and bmp7 induce the white-to-brown transition of primary human adipose stem cells. Am J Physiol Cell Physiol. 2014;306: C431-440.

[40] Sae-Tan S, Rogers CJ, Lambert JD. Decaffeinated green tea and voluntary exercise induce gene changes related to beige adipocyte formation in high fat-fed obese mice. J Funct Foods. 2015;14:210-214.

[41] Bartelt A, Heeren J. Adipose tissue browning and metabolic health. Nat Rev Endocrinol. 2014;10:24-36.

[42] Shahid M, Javed AA, Chandra D, et al. Iex-1 deficiency induces browning of white adipose tissue and resists diet-induced obesity. Sci Rep. 2016;6:24135.

[43] Shin JH, Lee SH, Kim YN, et al. Ahnak deficiency promotes browning and lipolysis in mice via increased responsiveness to beta-adrenergic signalling. Sci Rep. 2016;6:23426.

[44] Owen BM, Ding X, Morgan DA, et al. Fgf21 acts centrally to induce sympathetic nerve activity, energy expenditure, and weight loss. Cell Metab. 2014;20:670-677.

[45] Ahmadian M, Suh JM, Hah N, et al. Ppar gamma signaling and metabolism: the good, the bad and the future. Nature Medicine. 2013;19:557-566.

[46] Ahmadian M, Duncan RE, Sul HS. The skinny on fat: lipolysis and fatty acid utilization in adipocytes. Trends Endocrin Met. 2009;20:424-428.

[47] Sugii S, Olson P, Sears DD, et al. Ppar gamma activation in adipocytes is sufficient for systemic insulin sensitization. P Natl Acad Sci USA. 2009;106:22504-22509.

[48] Kersten S. Peroxisome proliferator activated receptors and obesity. Eur J Pharmacol. 2002;440:223-234.

[49] Tian C, Ye XL, Zhang R, et al. Green tea polyphenols reduced fat deposits in high fat-fed rats via erk1/2-ppar gamma-adiponectin pathway. PLoS One. 2013;8:53796.

[50] Bhattarai BR, Kafle B, Hwang JS, et al. Novel thiazolidinedione derivatives with anti-obesity effects: dual action as ptp1b inhibitors and ppar-gamma activators. Bioorg Med Chem Lett. 2010;20:6758-6763.

[51] Yamauchi T, Kamon J, Minokoshi Y, et al. Adiponectin stimulates glucose utilization and fatty-acid oxidation by activating amp-activated protein kinase. Nat Med. 2002;8:1288-1295.

[52] Fruebis J, Tsao T-S, Javorschi S, et al. Proteolytic cleavage product of $30-\mathrm{kda}$ adipocyte complement-related protein increases fatty acid oxidation in muscle and causes weight loss in mice. P Natl Acad Sci USA. 2001;98:2005-2010.

[53] Bell-Anderson KS, Aouad L, Williams H, et al. Coordinated improvement in glucose tolerance, liver steatosis and obesity-associated inflammation by cannabinoid 1 receptor antagonism in fat aussie mice. Int J Obesity. 2011;35:1539-1548.

[54] Iwaki M, Matsuda $M$, Maeda $N$, et al. Induction of adiponectin, a fat-derived antidiabetic and antiatherogenic factor, by nuclear receptors. Diabetes. 2003;52:1655-1663.

[55] Yamauchi T, Kamon J, Waki H, et al. The fat-derived hormone adiponectin reverses insulin resistance associated with both lipoatrophy and obesity. Nat Med. 2001;7:941-946.

[56] Barnea M, Shamay A, Stark AH, et al. A high-fat diet has a tissue-specific effect on adiponectin. And related enzyme expression. Obesity. 2006;14:2145-2153.

[57] Arita Y, Kihara S, Ouchi N, et al. Paradoxical decrease of an adipose-specific protein, adiponectin, in obesity. Biochem Bioph Res Co. 1999;257:79-83. 
[58] Soares FLP, Matoso RD, Teixeira LG, et al. Gluten-free diet reduces adiposity, inflammation and insulin resistance associated with the induction of ppar-alpha and ppar-gamma expression. J Am Coll Nutr. 2013;24:1105-1111.

[59] Fromme T, Klingenspor M. Uncoupling protein 1 expression and high-fat diets. Am J Physiol Regul Integr Comp Physiol. 2011;300:R1-8.

[60] Rocha-Rodrigues S, Rodriguez A, Gouveia AM, et al. Effects of physical exercise on myokines expression and brown adipose-like phenotype modulation in rats fed a high-fat diet. Life Sci. 2016;165:100-108.

[61] Shepherd PR, Kahn BB. Glucose transporters and insulin action-implications for insulin resistance and diabetes mellitus. N Engl J Med. 1999;341:248-257.

[62] Fiorini RN, Donovan JL, Rodwell D, et al. Short-term administration of (-)-epigallocatechin gallate reduces hepatic steatosis and protects against warm hepatic ischemia/reperfusion injury in steatotic mice. Liver Transpl. 2005;11:298-308.

[63] Hasler CM. Functional foods: their role in disease prevention and health promotion. Food Technol-Chicago. 1998;52:63-70.
[64] Galati G, Lin A, Sultan AM, et al. Cellular and in vivo hepatotoxicity caused by green tea phenolic acids and catechins. Free Radical Bio Med. 2006;40:570-580.

[65] Cabrera C, Artacho R, Gimenez R. Beneficial effects of green tea-a review. J Am Coll Nutr. 2006;25:79-99.

[66] Lattanzio V, Kroon PA, Linsalata V, et al. Globe artichoke: a functional food and source of nutraceutical ingredients. J Funct Foods. 2009;1:131-144.

[67] Alissa EM, Ferns GA. Functional foods and nutraceuticals in the primary prevention of cardiovascular diseases. J Nutr Metab. 2012;2012:569486.

[68] Chadwick R, Henson S, Moseley B, et al. Functional foods. Vol. 20. New York (NY): Springer Science \& Business Media; 2003.

[69] Wasser SP, Akavia E. Regulatory issues of mushrooms as functional foods and dietary supplements: safety and efficacy. In: Cheung PCK, editor. Mushrooms as functional foods. New York (NY): Wiley; 2008. p. 199-221.

[70] Thavanesan N. The putative effects of green tea on body fat: an evaluation of the evidence and a review of the potential mechanisms. Brit J Nutr. 2011;106:1297-1309. 